\title{
A dynamic causality test of exports and economic growth in Zimbabwe
}

\author{
Kunofiwa Tsaurai* \\ Department of Finance, Risk Management and Banking, \\ University of South Africa, \\ P.O. Box 392, UNISA, 0003, Pretoria, South Africa \\ E-mail: tsaurk@unisa.ac.za \\ E-mail: kunofiwa.tsaurai@gmail.com \\ *Corresponding author
}

\section{Nicholas M. Odhiambo}

Department of Economics, University of South Africa,

P.O. Box 392, UNISA, 0003, Pretoria, South Africa

E-mail: odhianm@unisa.ac.za

E-mail:nmbaya99@yahoo.com

\begin{abstract}
In this paper, we examine the causal relationship between export growth and economic growth. The causal relationship between exports and economic growth has been a subject of extensive debate in recent years. There are currently three dominant views regarding the relationship between exports and economic growth. The first view maintains that it is the growth of exports that drives economic growth. The second view argues that it is economic growth that spurs exports expansion; while the third view maintains that both exports and economic growth promote one another. Using the autoregressive distributed lag (ARDL)-bounds testing approach, we find that there is a distinct causal flow from export growth to economic growth in Zimbabwe - both in the short run and in the long run. We therefore recommend that policies, which are geared towards export promotion should be intensified, in order to promote long-term economic growth in Zimbabwe.
\end{abstract}

Keywords: Zimbabwe; exports; economic growth; ARDL-bounds testing approach.

Reference to this paper should be made as follows: Tsaurai, K. and Odhiambo, N.M. (2012) 'A dynamic causality test of exports and economic growth in Zimbabwe', Int. J. Economic Policy in Emerging Economies, Vol. 5, No. 3, pp.231-242.

Biographical notes: Kunofiwa Tsaurai is a Lecturer in Financial Management. His main areas of research interest include stock market development, foreign direct investment, monetary economics, international banking and finance, investments, credit management and risk management.

Nicholas M. Odhiambo is Professor of Economics and Chair of Growth, Poverty and Policy Modelling (GPPMR) Research. 


\section{Introduction}

One of the fundamental questions that economists seek to answer is how countries can achieve long-term economic growth. According to Ben-David and Loewy (1998), the solution to the above question arguably depends on the export-led growth (ELG) hypothesis which postulates that exports expansion, especially of manufactured goods, is a key factor in promoting economic growth. According to Mookerjee (2006), the exports-growth nexus elicited more controversy and interest in the last three decades than any other area of academic research. Both theoretical and empirical literature available to date lack consensus in as far as the direction of causality between exports and economic growth is concerned, argued Mookerjee (2006). What is clear is that the policies based on the full understanding of the exports-growth nexus have the ability to lift millions of the world's poor out of poverty (Berg and Krueger, 2002).

At the heart of this debate lies the question of whether economic growth is driven by exports, whether it is exports growth that is driven by economic growth or the two variables promote each other. The foundation of this debate can be traced back to the classical economic theorist (Smith, 1776) who demonstrated the effect of international trade on economic growth. This debate is particularly important for the sub-Saharan African region, where about 29 countries are currently classified as low-income economies. In fact, only about five countries of the total $+/-49$ countries in sub-Saharan Africa (SSA) are currently classified as upper middle-income countries. This has forced many SSA countries to embark on various strategies, which are aimed at boosting economic growth. In Zimbabwe, for example, the government has over the years formulated and implemented several export growth promotion policies and strategies in a bid to boost economic growth. These include the export promotion programme (EPP), the export revolving fund (ERF), the export retention scheme (ERS), the export bonus scheme (EBS) and the export processing zones (EPZs).

Unfortunately, very few studies have been conducted to investigate the relationship between exports and economic growth in Zimbabwe. These include a study on the time series evidence for export-led growth paradigm by Ogbokor (2005) and export-led growth hypothesis by Chigusiwa et al. (2011). However, these previous studies on this subject over-relied on cross-sectional data, which may not address the country's specific issues. The problem of using the cross-sectional method is that by grouping together countries that are at different stages of economic development, the country-specific effects of exports on economic growth and vice-versa are not addressed (see Odhiambo, 2008; Ghirmay, 2004; Casselli et al., 1996; Quah, 1993).

It is against this background that the current study aims to examine the relationship between exports and economic growth in Zimbabwe using the recently developed autoregressive distributed lag (ARDL)-bounds testing approach. The study uses exports of goods and services expressed as a ratio of gross domestic product (GDP) as a proxy for exports growth, whilst real GDP per capita is used as a proxy for economic growth. The results of this study is valuable to economic policy makers, as it enables them to prescribe the correct economic policy mix (exports policy included) required to steer the Zimbabwe economy out of the decade long economic doldrums it has been trapped in.

The rest of the paper is structured as follows: Section 2 gives an overview of exports and economic growth in Zimbabwe. Section 3 presents the theoretical and empirical literature review, while Section 4 deals with the empirical model specification, the 
estimation technique and the empirical analysis of the regression results. Section 5 concludes the study.

\section{Exports and economic growth in Zimbabwe}

According to the Reserve Bank of Zimbabwe (RBZ, 1982), Zimbabwe (then called Rhodesia) adopted a set of restrictive trade policies and an extensive set of foreign exchange controls as a strategy to counter international trade sanctions imposed on the country between 1965 and 1979. After independence in 1980, the new Zimbabwean government retained many of the restrictive policies and controls of the previous government and this resulted in foreign exchange shortages. According to the RBZ (1985), the Zimbabwean government responded to the foreign exchange crisis by introducing export incentives such as the EPP, the ERF, the ERS and the EBS.

The debate to structurally adjust the economy during late 1988 then came up, as stated in the policy reform document, Economic Structural Adjustment Programme (ESAP, 1991). The argument was centred on the fact that trade openness and free market policies were vital in promoting exports and economic growth (World Bank, 1987). The World Bank and the International Monetary Fund (IMF) overwhelmingly backed the concept, which then saw the implementation of the ESAP in November 1990. The adoption of trade liberalisation policy under ESAP in 1990 was equivalent to pursuing an ELG policy by the Zimbabwean government.

Figure 1 Exports of goods and services for Zimbabwe (1981-2010) (see online version for colours)

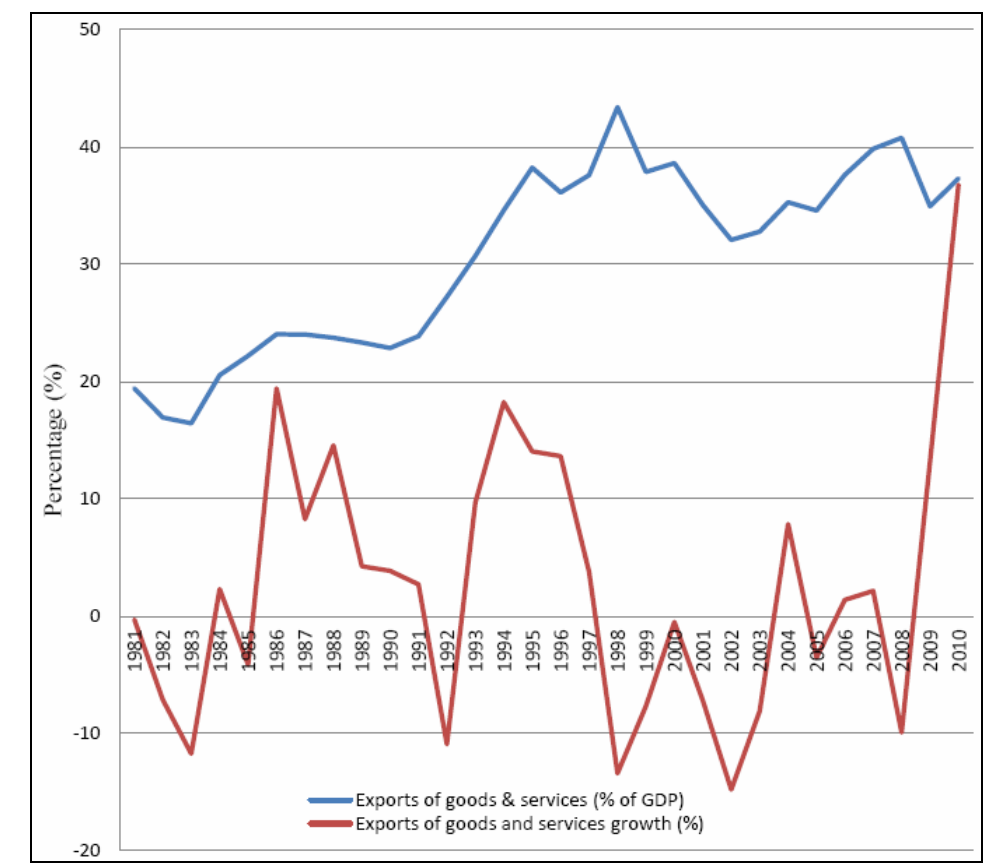

Source: World Bank (2011) 
According to the IMF (2004), the trade liberalisation policy in Zimbabwe resulted in an increase in export growth from $2.5 \%$ during the 1980 s to $6.9 \%$ between 1991 and 1995 and $15.5 \%$ for the period 1996 to 2000 although they decreased again to $-1.1 \%$ between 2001 and 2004. Exports were further stimulated throughout the 1990s by the continued devaluation of the local currency by more than $400 \%$ between 1991 and 2000 (RBZ, 2000). EPZs that were established in 1995 to boost foreign direct investments (FDI) resulted in an increase in manufacturing sector exports (RBZ, 2000). Export volumes remained very low during period 2004 to 2008, despite the implementation of exports growth promotion strategies by the RBZ in conjunction with the Zimbabwean Ministry of Finance (ZimTrade, 2010). These exports promotion efforts included a $100 \%$ export proceeds retention facility, a loan facility at below market interest rates for exporters and an export tax exemption facility. According to ZimTrade (2010), although Zimbabwe's export growth went up by $36.79 \%$ during the period 2009 to 2010 , the performance of value-added exports was minimal as the manufacturing sector continued to grapple with a number of capacity utilisation challenges. Figure 1 shows trends of export of goods and services for Zimbabwe from 1981 to 2010.

Figure 2 Economic growth trends for Zimbabwe (1982-2010) (see online version for colours)

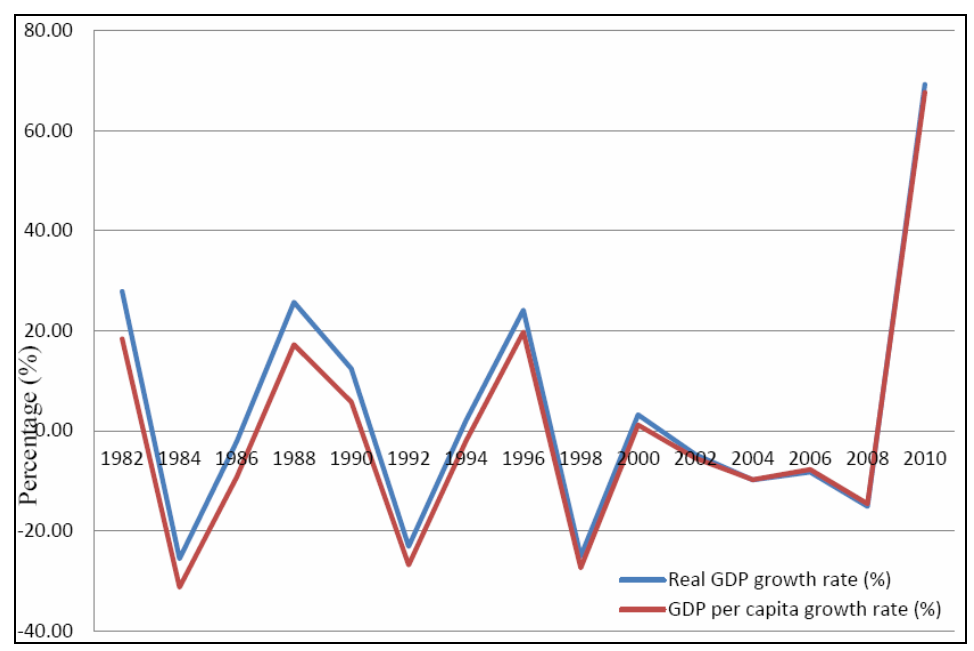

Source: World Bank (2011)

According to the World Bank (2011), exports of goods and services grew by a negative $19.79 \%$, from US $\$ 1.56$ billion in 1980 to US $\$ 1.25$ billion in 1985 . The period from 1985 to 1990 saw exports of goods and services increasing from US $\$ 1.25$ billion to US $\$ 2.008$ billion, representing a surge of $60.45 \%$. The subsequent five year period recorded a further increase in exports of goods and services in Zimbabwe from US $\$ 2.008$ billion in 1990 to US $\$ 2.72$ billion in 1995. Exports of goods and services went down by $6.13 \%$ between 1995 and 2000 before experiencing another decline by a further $24.37 \%$, from US $\$ 2.55$ billion in 2000 to US $\$ 1.93$ billion in 2005 . This was a culmination of the investor confidence being rattled in 2000 when compulsory farm acquisitions enabled by an Act of parliament began. Exports of goods and services in Zimbabwe recorded a huge increase of $44.51 \%$ during the period from 2005 to 2010 . This 
contributed to the better performance of the Zimbabwean economy as shown by the ratio of exports of goods and services to GDP going up from $34.58 \%$ in 2005 to $37.33 \%$ in 2010. Economic growth in Zimbabwe was punctuated by three different phases from 1985 up to 2010, with positive economic growth recorded from 1985 to 1990 and negative economic growth from 1991 to 2008 whilst 2009 and 2010 was a recovery period. Figure 2 shows the trends of real GDP growth and per capital GDP growth in Zimbabwe during the period between 1982 and 2010.

\section{Literature review}

There are three views that exist in the literature regarding the relationship between exports and economic growth. These include the ELG, the growth-led export (GLE), and finally, the view which maintains that there is a bidirectional causal relationship between exports and growth.

The ELG view is supported by Chenery and Strout (1966), Ben-David and Loewy (1998), Hart (1983), Feder (1982), Esfahani (1991), Balassa (1978), amongst others. According to Chenery and Strout (1966), an increase in export earnings brings in more foreign exchange, hence making it easier to import inputs to meet domestic production and output growth. Hart (1983), as well as Ben-David and Loewy (1998) are other proponents of the ELG view. According to these authors, exports give access to advanced technologies, learning by doing gains and better management practices. These, in turn, stimulate technological diffusion into the economy. According to Feder (1982), exports generate positive externalities in non-export sectors through enhancing more efficient management styles and production techniques. Esfahani (1991) concurred with Feder (1982), but stressed that exports mitigate foreign exchange constraints, thereby providing the economy with greater access to international markets. ELG proponents believe that exports allow for the more efficient utilisation of resources. Balassa (1978) also revealed that exports generate foreign currency that can be used to import capital equipment that in turn stimulates economic growth.

Empirical studies that are consistent with the ELG view include those undertaken by Rangasamy (2009), Jaunky (2011), Konya (2006), Awokuse (2007), Pradhan (2010), Aditya and Acharyya (2011), Parida and Sahoo (2007), Siliverstovs and Herzer (2006), Al Mamun and Nath (2005), and Yoo (2008), amongst others. Rangasamy (2009) revealed a uni-directional causality running from exports to real GDP in South Africa. Exports constitute a larger contribution to non-export GDP growth in South Africa, argued Rangasamy (2009). Jaunky (2011) discovered a unidirectional causality relationship running from fish exports to real GDP in the long run for the small island developing states (SIDS). Konya (2006), while investigating the direction of causality between exports and economic growth in 24 Organisation for Economic Co-operation and Development (OECD) countries, found a unidirectional causality from exports to GDP in Belgium, Denmark, Iceland, Ireland, Italy, New Zealand, Spain and Sweden. The results from an ELG hypothesis test in Bangladesh by Al Mamun and Nath (2005) discovered a positive long-run relationship running from exports to real GDP. A study by Awokuse (2007) also provided empirical support for the export-led growth hypothesis in the Czech Republic. This finding is similar to that of Pradhan (2010), whose study also revealed Granger causality running only from exports growth to GDP growth in India. 
Net of exports GDP in Chile were also discovered to have been Granger-caused by manufacturing sector exports, according to Siliverstovs and Herzer (2006). However, Aditya and Acharyya (2011) discovered that exports diversification and composition are the vital determinants of economic growth after controlling for the impact of other variables like lagged income, investment and infrastructure. A positive relationship between exports and economic growth becomes even stronger for countries whose portion of manufacturing sector exports in their total exports is greater than the world average, according to Aditya and Acharyya (2011). Parida and Sahoo (2007) concurred with this view, and went on to reveal other vital factors - apart from exports growth that influence economic growth in South Asian countries (Bangladesh, India, Pakistan and Sri Lanka), such as fixed capital formation and public expenditure on health and education.

A study by Yoo (2008) also indicated a high statistical significance of the estimated coefficient of high technology (HT) exports, in so far as its influence on economic growth is concerned. According to Keong et al. (2005), the bounds testing approach discovered that exports stimulated positive economic growth in Malaysian economy both in the short and long run. Al Mamun and Nath (2005) also discovered that both industrial production and exports were co-integrated in Bangladesh with a distinct long run unidirectional causality running from exports to economic growth.

The GLEs view is supported by Bhagwati (1988), who argued that an increase in economic growth leads to more exports. Economic growth leads to the enhancement of skills, technology and a comparative advantage for the country that facilitates exports, argued Bhagwati (1988). Empirical studies that are consistent with the GLE view include those undertaken by Konya (2006), Lim (2011), Baimbridge and Zang (2011) and Mishra (2011), amongst others. Konya (2006), while using a Granger-causality test and a panel data approach on OECD countries, discovered a one-way causality from GDP to exports in Austria, France, Greece, Japan, Mexico, Norway and Portugal. Lim (2011) in a study in Indonesia concurred with Konya (2006) but further stressed that economic growth in developing countries leads to the enrichment of skills and improvements in technology. This creates a comparative advantage that stimulates exports for the developing country. On the contrary, Baimbridge and Zang (2011) found that economic growth had a negative impact on exports in South Korea. In a study for India over a period 1970 to 2009, Mishra (2011) revealed a Granger causality running from GDP to exports in the long run but not in the short run. This finding rejected the export-led growth hypothesis in India.

The third view (i.e., the feedback view) maintains that both exports and economic growth promotes one another. Empirical studies that are consistent with the feedback view include those undertaken by Awokuse (2005, 2007), Konya (2006), Tsen (2010), Narayan and Smyth (2004), Lim (2011), Mah (2006) and Jin and Shih (1995), amongst others. Awokuse (2005) revealed a bidirectional causal linkage between exports and real GDP growth in Korea. The same study revealed that Korea simultaneously experienced periods when economic growth was export-led, as advocated by export-led growth (ELG) proponents and also periods when exports were growth-driven. Tsen (2010) found bidirectional Granger causality among exports, domestic demand and economic growth in China. Exports and domestic demand positively affected economic growth whilst the latter also had a positive impact on exports and domestic demand in China, according to 
Tsen (2010). These findings were also consistent with those of Liu et al. (1997) and Shan and Sun (1998), who did similar studies in China. However, the finding is in contrast with the findings of Narayan and Smyth (2004), who discovered neutrality between real exports and real GDP in China. Mah (2006) also revealed bidirectional causality between exports and economic growth in China - which agrees with that of Shan and Sun (1998).

The findings by Awokuse (2007) in the case of Bulgaria supported the existence of both export-led growth and GLEs hypotheses. Lim (2011) found evidence that support bidirectional causality between GDP per capita and export growth in Malaysia and Thailand. In a study in Asia, Jin and Shih (1995) discovered results that were at variance with the ELG hypothesis but consistent with the feedback view in which exports and economic growth reinforce each other in the short run. In addition, a two-way (feedback) relationship between exports and economic growth in OECD countries (Canada, Finland and Netherlands) was also discovered in a study by Konya (2006).

\section{Empirical model specification and estimation technique}

\subsection{Data sources and definition of variables}

The annual data which spans between 1980 and 2010 was used in this study. The data used in this study were obtained from the various issues of the International Financial Statistics (IFS) Yearbook, the World Development Indicators and the African Development Indicators. The export variable was expressed as a share of GDP, while the economic growth variable was measured by real GDP per capita.

\subsection{Unit root tests}

Like many other time-series data, the variables - real per capita GDP and exports - were tested for stationarity, before running the causality test. The results of the stationarity tests in levels and on differenced variables are presented in Tables 1 and 2, respectively.

The results of the unit root tests reported in Tables 1 and 2 show that both $y / N$ and EXPORT are integrated of order 1.

Table 1 Sationarity tests of variables in levels

\begin{tabular}{lccc}
\hline Variable & No trend & Trend & Stationarity status \\
\hline \multicolumn{4}{c}{ Stationarity tests of variables in levels: ADF test } \\
\hline Ly/GDP & -0.667121 & -2.079225 & $\mathrm{I}(1)$ \\
LEXPORT & 0.798921 & -1.934668 & $\mathrm{I}(1)$ \\
\hline \multicolumn{4}{c}{ Stationarity tests of variables in levels: Philip-Perron (PP) test } \\
\hline Ly/GDP & -0.893810 & -1.033057 & $\mathrm{I}(1)$ \\
LEXPORT & 0.694628 & -2.174505 & $\mathrm{I}(1)$ \\
\hline \multicolumn{5}{c}{ Stationarity tests of all variables in levels: DF-GLS tests } \\
\hline Ly/GDP & -1.273215 & -2.394164 & $\mathrm{I}(1)$ \\
LEXPORT & -0.766863 & -1.908402 & $\mathrm{I}(1)$ \\
\hline
\end{tabular}


Table 2 Stationarity tests of variables in first difference

\begin{tabular}{lccc}
\hline Variable & No trend & Trend & Stationarity status \\
\hline \multicolumn{4}{c}{ Stationarity tests of variables in first difference: ADF test } \\
\hline DLy/GDP & $-3.796632^{* * *}$ & $-3.891987^{* *}$ & Stationary \\
DLEXPORT & $-3.288468^{* * *}$ & $-4.197775^{* *}$ & Stationary \\
\hline \multicolumn{4}{c}{ Stationarity tests of variables in first difference: PP test } \\
\hline DLy/GDP & $-3.630027^{* * *}$ & $-3.655902^{* *}$ & Stationary \\
DLEXPORT & $-4.416069^{* * *}$ & $-4.565646^{* * *}$ & Stationary \\
\hline \multicolumn{5}{c}{ Stationarity tests of all variables in first difference: DF-GLS tests } \\
\hline DLy/GDP & $-3.198414^{* * *}$ & $-3.865870^{* * *}$ & Stationary \\
DLEXPORT & $-3.383382^{* * *}$ & $-4.029576^{* * *}$ & Stationary \\
\hline
\end{tabular}

Notes: The truncation lag for the PP tests is based on Newey and West (1987) bandwidth.

$* *$ and $* * *$ denote significance at $5 \%$ and $1 \%$ respectively. Critical values for

Dickey-Fuller GLS test are based on Elliot-Rothenberg-Stock [Elliot et al.,

(1996), Table 1].

\subsection{Cointegration test-ARDL-bounds testing procedure}

Having confirmed that the two variables are not integrated of order 2, we can now proceed to examine the existence of a co-integrating vector - using the recently developed ARDL-bounds testing approach. The ARDL model used in this study can be expressed as follows:

$$
\begin{aligned}
\Delta \operatorname{Iny} / N_{t}= & a_{0}+\sum_{i=1}^{n} a_{1 i} \Delta \operatorname{Iny} / N_{t-i} \\
& +\sum_{i=0}^{n} a_{2 i} \Delta \operatorname{InEXPOR} T_{t-i}+a_{3} \operatorname{Iny} / N_{t-1}+a_{4} \operatorname{InEXPORT} T_{t-1}+\mu_{t} \\
\Delta \operatorname{InEXPORT} T_{t}= & \beta_{0}+\sum_{i=1}^{n} \beta_{1 i} \Delta \operatorname{InEXPORT} T_{t-i} \\
& +\sum_{i=0}^{n} \beta_{2 i} \operatorname{Iny} / N_{t-i}+\beta_{3} \operatorname{Iny} / N_{t-1}+\beta_{4 i} \operatorname{InEXPOR} T_{t-1}+\mu_{t}
\end{aligned}
$$

where

\section{InEXPORT $\log$ of export variable}

$y / N \quad$ real GDP per capita

$\Delta \quad$ first difference operator.

In the first step of the ARDL-bounds test, we examine the order of lags on the first differenced variables in equations (1) and (2) - using the Akaike information criterion (AIC) and the Schwartz-Bayesian criterion (SBC). The results of the AIC and SBC tests (not reported here) indicate that the optimal lag of $\mathrm{y} / \mathrm{N}$ is lag 1 ; while that of EXPORT is 
lag 3. After determining the optimal lag, we apply the bounds F-test to equations (1) and (2), in order to assess the existence of any long-run relationship between $\mathrm{y} / \mathrm{N}$ and EXPORT. The results of the bounds test are reported in Table 3.

Table 3 Bounds F-test for co-integration

\begin{tabular}{|c|c|c|c|c|c|c|}
\hline Dependent variable & \multicolumn{3}{|c|}{ Function } & \multicolumn{3}{|c|}{$F$-test statistic } \\
\hline$y / N$ & \multicolumn{3}{|c|}{$\mathrm{y} / \mathrm{N}(\mathrm{EXPORT})$} & \multicolumn{3}{|c|}{$3.8688^{*}$} \\
\hline EXPORT & \multicolumn{3}{|c|}{$\operatorname{EXPORT}(\mathrm{y} / \mathrm{N})$} & \multicolumn{3}{|c|}{3.3530} \\
\hline \multicolumn{7}{|c|}{ Asymptotic critical values } \\
\hline & \multicolumn{2}{|c|}{$1 \%$} & \multicolumn{2}{|c|}{$5 \%$} & \multicolumn{2}{|c|}{$10 \%$} \\
\hline & $I(0)$ & $I(1)$ & $I(0)$ & $I(1)$ & $I(0)$ & $I(1)$ \\
\hline $\begin{array}{l}\text { Pesaran et al. (2001, p.300, } \\
\text { Table CI(ii) Case II) }\end{array}$ & 4.94 & 5.58 & 3.62 & 4.16 & 3.02 & 3.51 \\
\hline
\end{tabular}

Note: * denotes statistical significance at the $10 \%$ level.

The results, reported in Table 3, show that there is a long-run relationship between $y / N$ and EXPORT, but only in the $\mathrm{y} / \mathrm{N}$ equation. This is confirmed by the F-statistic, which is statistically significant in the $\mathrm{y} / \mathrm{N}$ equation, but not in the EXPORT equation. We therefore conclude that there is a unique co-integrating vector between $\mathrm{y} / \mathrm{N}$ and EXPORT.

\subsection{The Granger non-causality test}

The results reported in Section 4.3 show that there is a long-run relationship been exports and real GDP per capita. The next step, therefore, is to examine the Granger-causality between the two variables - using the following model (see Odhiambo, 2010; Narayan and Smyth, 2008).

$$
\begin{aligned}
& \Delta \operatorname{Iny} / N_{t}=\phi_{0}+\sum_{i=1}^{n} \phi_{i} \Delta \operatorname{Iny} / N_{t-i}+\sum_{i=0}^{n} \phi_{2 i} \Delta \operatorname{InEXPORTi_{t-i}}+E_{C M} M_{t-1}+\mu_{t} \\
& \Delta \operatorname{InExporti}_{t}=\delta_{0}+\sum_{i=1}^{n} \delta_{1 i} \Delta \operatorname{InExporti_{t-i}}+\sum_{i=0}^{n} \delta_{2 i} \Delta \operatorname{Iny} / N_{t-i}+E_{C M} M_{t-1}+\mu_{t}
\end{aligned}
$$

where $E C M_{t-1}=$ the lagged error-correction term obtained from the long-run equilibrium relationship.

Based on equations (3) and (4), the direction of the causality between exports and economic growth will be determined by the F-statistic and the lagged error-correction term. The F-statistic represents the short-run causal effect; while the lagged error-correction term represents the long-run causal relationship (see Odhiambo, 2010; Narayan and Smyth, 2006). The results of these causality tests are reported in Table 4.

The empirical results reported in Table 4 show that export growth Granger-causes economic growth - irrespective of whether the causality is estimated in the short run or in the long run.. This finding is confirmed by the F-statistic and the coefficient of the error-correction term, which are statistically significant in the economic growth function, but not in the exports function. 
Table 4 Granger non-causality tests

\begin{tabular}{|c|c|c|c|c|}
\hline Dependent variable & Causal flow & F-statistic & $\begin{array}{c}t \text {-test on } \\
\text { ECM }\end{array}$ & $R^{2}$ \\
\hline Economic growth $(\mathrm{y} / \mathrm{N})$ & Exports $\rightarrow$ economic growth $(y / N)$ & 8.5781 & 3.422 & 0.91 \\
\hline Exports & Economic growth $(\mathrm{y} / \mathrm{N}) \rightarrow$ exports & 1.7054 & - & 0.81 \\
\hline
\end{tabular}

\section{Conclusions}

This paper has investigated the dynamic relationship between exports and economic growth in Zimbabwe - using the time-series data from 1980 to 2010. The causal relationship between exports and economic growth has been a subject of extensive debate in recent years. Currently, there exist three dominant views regarding the relationship between exports and economic growth. The first view maintains that it is the growth of exports that drive economic growth. The second view argues that it is economic growth that spurs the growth of exports whilst the third view maintains that both exports and economic growth reinforce each other. Contrary to other previous studies, this research has employed the recently developed ARDL-bounds testing approach to investigate the causal relationship between exports and economic growth in Zimbabwe. The empirical results show that there is a distinct unidirectional Granger causality running from export growth to real GDP per capita without any feedback in Zimbabwe. This applies both in the short run and in the long run. The study, therefore, recommends that Zimbabwe should intensify its export growth promotion policies and strategies in order to boost economic growth.

\section{References}

Aditya, A. and Acharyya, R. (2011) 'Export diversification, composition and economic growth: evidence from cross country analysis', The Journal of International Trade and Economic Development, Vol. 20, No. 1, pp.1-34.

Al Mamun, K.A. and Nath, H.K. (2005) 'Export-led growth in Bangladesh: a time series analysis', Applied Economic Letters, Vol. 12, No. 6, pp.361-364.

Awokuse, T.O. (2005) 'Exports, economic growth and causality in Korea', Applied Economic Letters, Vol. 12, No. 11, pp.693-696.

Awokuse, T.O. (2007) 'Causality between exports, imports and economic growth: evidence from transition economies', Economic Letters, Vol. 94, No. 1, pp.389-395.

Baimbridge, M. and Zang, W. (2011) 'Exports, imports and economic growth in South Korea and Japan: a tale of two economies', Applied Economics, Vol. 44, No. 3, pp.361-372.

Balassa, B. (1978) 'Exports and economic growth: further evidence', Journal of Development Economics, Vol. 5, No. 2, pp.181-189.

Ben-David, D. and Loewy, M.B. (1998) 'Free trade, growth and convergence', Journal of Economic Growth, Vol. 3, No. 2, pp.143-170.

Berg, A. and Krueger, A. (2002) 'Lifting all boats: why openness helps curbs poverty', Finance and Development, Vol. 39, No. 3, pp.16-21.

Bhagwati, J. (1988) 'Exports promoting trade strategy: issues and evidence', World Bank Research Observer, Vol. 3, No. 1, pp.27-58. 
Casselli, F., Esquivel, G. and Lefort, F. (1996) 'Reopening the convergence debate: a new look at cross-country growth empirics', Journal of Economic Growth, Vol. 1, No. 3, pp.363-389.

Chenery, H.B. and Strout, A.M. (1966) 'Foreign assistance and economic development', The American Economic Review, Vol. 56, No. 4, pp.679-733.

Chigusiwa, L., Bindu, S., Mudavanhu, V., Muchabaiwa, L. and Muzarabani, D. (2011) 'Export-led growth hypothesis in Zimbabwe: does export composition matter?', Int. J. Eco. Res., Vol. 2, No. 4, pp.111-129.

Elliot, G., Rothenberg, T. and Stock, J. (1996) 'Efficient tests for an autoregressive unit root', Econometrica, Vol. 64, No. 4, pp.813-836.

ESAP (1991) Zimbabwe Economic Structural Adjustment Programme (ESAP) Policy.

Esfahani, H.S. (1991) 'Exports, imports and economic growth in semi-industrialized countries', Journal of Development Economics, Vol. 35, No. 1, pp.93-116.

Feder, G. (1982) 'On exports and economic growth', Journal of Development Economics, Vol. 12, No. 1, pp.59-73.

Ghirmay, T. (2004) 'Financial development and economic growth in sub-Saharan African countries: evidence from time series analysis', African Development Review, Vol. 16, No. 3, pp.415-432.

Hart, O. (1983) 'The market mechanism as an incentive scheme', Bell Journal of Economics, Vol. 14, No. 2, pp.366-382.

IMF (2004) International Monetary Fund (IMF) Report on Zimbabwe.

Jaunky, V.C. (2011) 'Fish exports and economic growth: the case of SIDS', Coastal Management, Vol. 39, No. 4, pp.377-395.

Jin, J.C. and Shih, Y.C. (1995) 'Export-led growth and the four little dragons', The Journal of International Trade and Economic Development, Vol. 4, No. 2, pp.203-215.

Keong, C.C., Yusop, Z. and Sen, V.L.K. (2005) 'Export-led growth hypothesis in Malaysia: an investigation using bounds test', Sunway Academic Journal, Vol. 2, No. 1, pp.13-22.

Konya, L. (2006) 'Exports and growth: Granger causality analysis on OECD countries with a panel data approach', Economic Modelling, Vol. 23, No. 6, pp.978-992.

Lim, S.Y. (2011) 'Export and economic growth in Southeast Asia current newly industrialised countries: evidence from nonparametric approach', Economics Bulletin, Vol. 31, No. 3, pp.2683-2693.

Liu, X., Song, H. and Romily, P. (1997) 'An empirical investigation of the causal relationship between openness and economic growth in China', Applied Economics, Vol. 29, No. 12, pp.1679-1687.

Mah, J.S. (2006) 'Export expansion, economic growth and causality in China', Applied Economic Letters, Vol. 12, No. 2, pp.105-107.

Mishra, P.K. (2011) 'Exports and economic growth', SCMS Journal of Indian Management, Vol. 8, No. 2, pp.17-26.

Mookerjee, R. (2006) 'A meta-analysis of the export growth hypothesis', Economic Letters, Vol. 91, No. 3, pp.395-401.

Narayan, P.K. and Smyth, R. (2004) 'Temporal causality and the dynamics of exports, human capital and real income in China', International Journal of Applied Economics, Vol. 1, No. 1, pp.24-45.

Narayan, P.K. and Smyth, R. (2006) 'Higher education, real income and real investment in China: evidence from Granger causality tests', Education Economics, Vol. 14, No. 1, pp.107-125.

Narayan, P.K. and Smyth, R. (2008) 'Energy consumption and real GDP in G7 countries: new evidence from panel cointegration with structural breaks', Energy Economics, Vol. 30, No. 5, pp.2331-2341.

Newey, W.K. and West, K.D. (1987) 'A simple, positive semi-definite, heteroskedasticity and auto-correlation consistent covariance matrix', Econometrica, Vol. 55, No. 3, pp.703-708. 
Odhiambo, N.M. (2008) 'Financial depth, savings and economic growth in Kenya: a dynamic causal linkage', Economic Modelling, Vol. 25, No. 4, pp.704-713.

Odhiambo, N.M. (2010) 'Finance-investment-growth nexus in South Africa: an ARDL-bounds testing approach', Economic Change and Restructuring, Vol. 43, No. 3, pp.205-219.

Ogbokor, C.A. (2005) 'Time series evidence for export-led growth paradigm: a case study of Zimbabwe', Journal of Social Sciences, Vol. 1, No. 2, pp.77-80.

Parida, P.C. and Sahoo, P. (2007) 'Export-led growth in South Asia: a panel cointergration analysis', International Economic Journal, Vol. 21, No. 2, pp.155-175.

Pesaran, M., Shin, Y. and Smith, R. (2001) 'Bounds testing approaches to the analysis of level relationships', Journal of Applied Econometrics, Vol. 16, No. 3, pp.289-326.

Pradhan, N.C. (2010) 'Exports and economic growth: an examination of ELG hypothesis for India', Reserve Bank of India Occasional Papers, Vol. 31, No. 3, pp.35-66.

Quah, D. (1993) 'Empirical cross-section dynamics in economic growth', European Economic Review, Vol. 37, No. 2, pp.426-434.

Rangasamy, L. (2009) 'Exports and economic growth: the case of South Africa', Journal of International Development, Vol. 21, No. 5, pp.603-617.

Reserve Bank of Zimbabwe (RBZ) (1982) Annual Report.

Reserve Bank of Zimbabwe (RBZ) (1985) Third Quarter Economic and Trade Review Report.

Reserve Bank of Zimbabwe (RBZ) (2000) Annual Economic Review.

Shan, J. and Sun, F. (1998) 'On the export-led growth hypothesis: the econometric evidence from China', Applied Economics, Vol. 30, No. 8, pp.1055-1065.

Siliverstovs, B. and Herzer, D. (2006) 'Export-led growth hypothesis: evidence for Chile', Applied Economics Letters, Vol. 13, No. 5, pp.319-324.

Smith, A. (1776) An Enquiry into the Nature and Causes of the Wealth of Nations, J.M Dent and Sons, London.

Tsen, W.H. (2010) 'Exports, domestic demand and economic growth in China: Granger causality analysis', Review of Development Economics, Vol. 14, No. 3, pp.625-639.

World Bank (1987) Making Finance Work for Africa, World Bank, Washington, DC.

World Bank (2011) World Development Indicators, World Bank, Washington, DC.

Yoo, S.H. (2008) 'High technology exports and economic output: an empirical investigation', Applied Economic Letters, Vol. 15, No. 7, pp.523-525.

ZimTrade (2010) Annual Report. 